\title{
Pluripotent Stem Cells in Bone Marrow and Cord Blood
}

\author{
Ambreen Shaikh and Deepa Bhartiya
}

Additional information is available at the end of the chapter

http://dx.doi.org/10.5772/48133

\section{Introduction}

In a short span of few years, the possibility that the human body contains cells that can repair and regenerate damaged and diseased tissue has become a reality. Adult stem cells have been isolated from numerous adult tissues, umbilical cord, and other non-embryonic sources, and have demonstrated a surprising ability for transformation into other tissue and cell types and for the repair of damaged tissues.

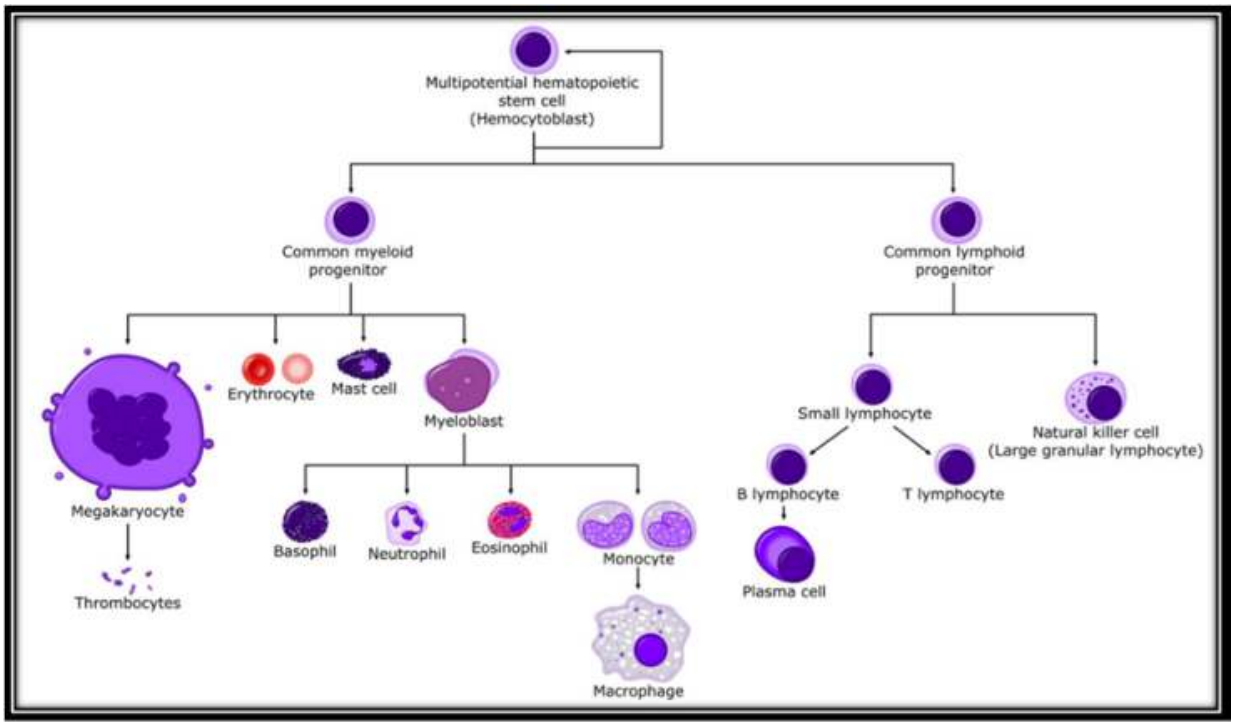

(Image: Hematopoiesis_(human)_diagram.png by A. Rad)

Figure 1. Hematopoiesis in Bone Marrow 
In the 1950s, researchers discovered that the bone marrow contains stem cells i.e. hematopoietic stem cells (HSC) with the ability to self-renew and give rise to cell types in the blood and immune system (Figure1). Multipotent HSCs reside at the apex of hematopoietic hierarchy and they are connected to mature cells by a complex roadmap of progenitor intermediates. The HSC differentiate into two different kinds of progenitors viz. Common Myeloid Progenitors (CMP) and Common Lymphoid Progenitors (CLP), which further differentiate to various blood cells including platelets, granulocytes, lymphocytes and macrophages. As a result, bone marrow transplantation became the standard method of care for most hematopoietic malignancies whereby the HSCs were able to repopulate bone marrow after any kind of hematopoietic failure. A recent review by Doulatov et al [1] describes the knowledge gathered over the years on Hematopoiesis.

Besides HSC, another stem cell population, the mesenchymal stem cells (MSC) was identified in the bone marrow about 40 years ago [2]. MSCs comprise of the adherent stem cell population with immune-modulatory properties. Besides bone marrow, MSCs can also be extracted from virtually all post-natal as well as extra-embryonic tissues such as amniotic membrane, placenta and umbilical cord. They can differentiate along multiple lineages and exhibit significant expansion capability in vitro. Co-transplantation with MSCs improves engraftment of HSCs after autologous intra-bone marrow transplantation [3]. MSCs are also considered useful as vehicles for emerging cell and gene therapies in the field of tissue engineering [4]. Recently it has been postulated that MSC provide the conducive microenvironment for HSCs and thus maintain the stemness and proliferation of HSCs and support HSC transplantation [3].

\section{Trans-differentiation of bone marrow stem cells}

Blood is one of the most highly regenerative tissues in our body with almost one trillion cells arising daily. Over the last decade several investigators have demonstrated that BM stem cells not only contribute to development of blood cells but also to the regeneration of various organs and tissues $[5,6]$. MSC isolated from various sources can differentiate into diverse cell types, showing a unique ability to cross lineage borders (i.e. are able to differentiate towards ectoderm-, mesoderm- and endoderm-derived cell types) and do not express the major histocompatibility complex (MHC) class II Human Leukocyte Antigen (HLA-DR) antigens. This, together with their in vitro proliferative potential and their immunoregulatory properties, renders them extremely promising for regenerative medicine applications in several diseases [7].

These observations were mainly explained by the hypothesis that the BM stem cells are 'plastic' and thus could dedifferentiate into various cell types of non-hematopoietic organs and tissues [8]. The possibility that HSC/MSC are plastic and able to trans-differentiate raised hope that $\mathrm{HSC} / \mathrm{MSC}$ isolated from $\mathrm{BM}$, mobilized into the peripheral blood ( $\mathrm{mPB}$ ) or cord blood (CB) could become a universal source of stem cells for tissue/ organ repair. This was supported by several demonstrations of the remarkable regenerative potential of HSC in animal models, for example after heart infarct [5], stroke [9], spinal cord injury [10], and 
liver damage [11] and of MSC in skeletal regeneration [12], cardiac regeneration [13], diabetes [14] and osteogeneis imperfect [15]. The potential of adult stem cells also resulted in slow growth of research and funding restrictions on ES cells during President Bush regime in USA - based on the argument that destroying embryos to derive human ES cell lines was not essential, when better alternatives including adult stem cells are available for regenerative medicine (http://en.wikipedia.org/wiki/Stem_cell_controversy). However the excitement over plasticity of HSC reduced when their role in repair of damaged organs became controversial $[16,17]$.

Several alternative mechanisms were proposed to explain the trans-differentiation of bone marrow stem cells [18] including (i) epigenetic changes i.e. factors present in the environment of damaged organs may induce epigenetic changes in the genes that regulate pluripotency of HSCs (ii) cell fusion during which infused HSCs may fuse with cells in damaged tissues and form heterokaryons which express markers of both donor and recipient cells (iii) paracrine effect i.e. HSCs are source of different trophic and angiopoietic factors that may promote tissue/organ repair (iv) microvesicles- dependent transfer of molecules like receptors, proteins and mRNA between HSC and damaged cells and (iv) presence of pluripotent stem cell population in the bone marrow in addition to HSC \& MSC that may contribute to regeneration. Presence of other stem cells in the BM may also explain the loss of contribution of BM cells to organ regeneration with the use of highly purified population of HSC [16]. Of these various possibilities (i) and (ii) are extremely rare and most likely the fact that BM houses heterogeneous and perhaps pluripotent stem cells may explain transdifferentiation potential of bone marrow. It has been demonstrated that there are heterogeneous stem cell populations in adult bone marrow compartment. Under appropriate experimental conditions, a certain type of bone marrow stem cells appears to differentiate (or transdifferentiate) into a variety of non-haemopoietic cells of ectodermal, mesodermal and endodermal origins (such as myocytes, neural cells and hepatocytes) [67].Various investigators have reported pluripotent stem cells in the bone marrow by using varied approaches to demonstrate their presence and are listed in Table 1.

The potential relationship of the BM-derived pluripotent stem cells reported by various investigators and compiled in Table1 is not clear. It is possible that these are overlapping populations of cells identified by slightly different isolation/ expansion strategies and likely that all of these versatile BM-derived Oct-4+ non-hematopoietic stem cells, which were given different names, are in fact very closely related to the same type of BM-residing Pluripotent Stem Cells (PSC). This overlap was elegantly described earlier by Ratajczak and his group [25] that various investigators are looking from different "keyholes" at the same population of stem cells that are hiding in a "darkroom" of the bone marrow environment. They further suggested that a 'founder cell' may exist in the bone marrow which is responsible for multi-lineage differentiation. Table 2 is a compilation of various markers reported on these differently described PSCs in the bone marrow responsible for their mobility (CXCR4), pluripotency (Oct-4, Nanog, Rex, Tert), non-hematopoietic lineage (CD45), immune status (MHC-1) and their developmental migration similarity to PGCs (SSEA1). 


\begin{tabular}{|c|c|}
\hline Stem Cell & Functional attributes (in brief) \\
\hline $\begin{array}{l}\text { MAPCs } \\
\text { Multipotent } \\
\text { Adult } \\
\text { Progenitor } \\
\text { Cells }\end{array}$ & $\begin{array}{l}\text { Described first by Verfailles and her group [19] } \\
\text { Extracted from bone marrow in mouse, rat and human } \\
\text { Plastic in nature and give rise to multiple cell types } \\
\text { Single MAPC in early mouse embryo can contribute to all body tissues } \\
\text { Ability to transdifferentiate } \\
\text { Do not form teratomas } \\
\text { SSEA-1+, CD13+, Flk-1low, Thy-1low, CD34-, CD44-, CD45-, CD117(c-kit)-, } \\
\text { MHC I-, MHC II-m SSEA1+, OCT-4+ } \\
\text { Can reconstitute bone marrow and also give rise to HSCs } \\
\text { Many characteristics like ES cells } \\
\text { MAPCs maintain telomere length } \\
\text { Pluripotent properties even after } 50 \text { doublings }\end{array}$ \\
\hline $\begin{array}{l}\text { MIAMI } \\
\text { Marrow } \\
\text { Isolated Adult } \\
\text { Lineage } \\
\text { Inducible Cells }\end{array}$ & $\begin{array}{l}\text { Bone marrow derived adult stem cells isolated in humans aged 3- } 72 \text { years [20] } \\
\text { Pluripotent by nature } \\
\text { Capable of differentiating into cells from all three germ layers } \\
\text { Positive for OCT-4, REX-1 and telomerase } \\
>50 \text { population doublings with no sign of senescence } \\
\text { Express markers typically associated with embryonic stem cells }\end{array}$ \\
\hline $\begin{array}{l}\text { RS cells } \\
\text { Recycling Stem } \\
\text { Cells }\end{array}$ & $\begin{array}{l}\text { Are a sub-population of cells present amongst the MSCs [21] } \\
\text { Small in size } \\
\text { Proliferate rapidly } \\
\text { CD45 }\end{array}$ \\
\hline $\begin{array}{l}\text { MACS } \\
\text { Multipotent } \\
\text { Adult } \\
\text { Progenitor } \\
\text { Cells }\end{array}$ & $\begin{array}{l}\text { Express pluripotent-state-specific transcription factors (OCT-4, Nanog and } \\
\text { Rex1[22] } \\
\text { Cloned from human liver, heart, and BM-isolated mononuclear cells } \\
\text { High telomerase activity } \\
\text { Wide range of differentiation potential. }\end{array}$ \\
\hline $\begin{array}{l}\text { MPCs } \\
\text { Mesodermal } \\
\text { Progenitor } \\
\text { Stem Cells }\end{array}$ & $\begin{array}{l}\text { Detected in bone marrow and cord blood [23] } \\
\text { Exist as a sub-population in MSC culture } \\
\text { Fail to divide in culture thus quiescent } \\
\text { Multi- to pluripotent by nature } \\
\text { Express SSEA-4, OCT-4, Nanog by IF and RT-PCR }\end{array}$ \\
\hline \begin{tabular}{l|} 
VSELs \\
Very Small \\
Embryonic-like \\
Stem Cells
\end{tabular} & $\begin{array}{l}\text { Homogenous population of rare ( } 0.01 \% \text { of BM mononuclear cells) Sca-1+ Lin- } \\
\text { CD } 45 \text { cells identified in murine BM [24] } \\
\text { Express SSEA-1, OCT- } 4 \text {, Nanog and Rex- } 1 \text { \& Rif- } 1 \text { telomerase protein } \\
\text { Small size ( 3.5 } \mu \mathrm{m} \text { in diameter) } \\
\text { Large nucleus surrounded by a narrow rim of cytoplasm } \\
\text { Open-type chromatin (euchromatin) } \\
\text { Differentiate into three lineages } \\
\text { Do not form teratoma } \\
\text { Quiescent population of cells }\end{array}$ \\
\hline
\end{tabular}

Table 1. Pluripotent Stem Cells Reported in the Bone Marrow 


\begin{tabular}{|l|l|l|l|l|l|}
\hline $\begin{array}{l}\text { Characteristics } \\
\text { Markers }\end{array}$ & MAPC & MIAMI & MACS & RS & VSEL \\
\hline Shape and size & $\begin{array}{l}\text { Form small } \\
\text { colonies in } \\
\text { culture }\end{array}$ & $\begin{array}{l}\text { Form small } \\
\text { colonies in } \\
\text { culture }\end{array}$ & Small & Small & Small \\
\hline CXCR4 & + & + & + & + & + \\
\hline CD 133 & ND & ND & - & - & + \\
\hline Sca 1 & ND & ND & ND & ND & + \\
\hline CD 45 & - & - & - & - & - \\
\hline OCT-4 & + & + & + & ND & + \\
\hline REX-1 & ND & + & + & ND & + \\
\hline Nanog & + & + & + & + & + \\
\hline TERT & + & + & ND & + & + \\
\hline SSEA 1 & + & ND & ND & ND & + \\
\hline MHC-1 & - & ND & + & ND & - \\
\hline $\begin{array}{l}\text { Quiescent by } \\
\text { nature }\end{array}$ & $\begin{array}{l}\text { No data } \\
\text { available }\end{array}$ & $\begin{array}{l}\text { No data } \\
\text { available }\end{array}$ & $\begin{array}{l}\text { No data } \\
\text { available }\end{array}$ & $\begin{array}{l}\text { No data } \\
\text { available }\end{array}$ & + \\
\hline $\begin{array}{l}\text { Teratoma } \\
\text { formation }\end{array}$ & $\begin{array}{l}\text { Do not form } \\
\text { teratoma }\end{array}$ & $\begin{array}{l}\text { Do not form } \\
\text { teratoma }\end{array}$ & $\begin{array}{l}\text { Do not form } \\
\text { teratoma }\end{array}$ & $\begin{array}{l}\text { Do not } \\
\text { form } \\
\text { teratoma }\end{array}$ & $\begin{array}{l}\text { Do not } \\
\text { form } \\
\text { teratoma }\end{array}$ \\
\hline
\end{tabular}

ND-experiment not done; + positive; - negative

Table 2. Compilation of Various Markers on BM Pluripotent Stem Cells

Besides these pluripotent stem cells, BM also houses Tissue Committed Stem Cells (TCSCs) including Epithelial Progenitor Cells (EPCs). Available literature suggests that postnatal neovascularization does not rely on formation of new blood vessels from pre-existing ones (angiogenesis) rather on EPCs migrating from the BM to induce neovascularization. EPCs and HSCs share certain markers like Flk-1, Tic2, Sca-1, and CD34. As a result it has been suggested that they both may arise from a common precursor [26].

Interestingly the trans-differentiation ability of adult BM cells into various TCSCs like hepatocytes, cardiomyocytes, vascular endothelial cells, neuronal cells etc. occurs only when there is a need i.e. into hepatocytes when damage is inflicted on the liver by radiation or chemical damage [27], into cardiomyocytes when myocardial infarction is induced [28], into endothelial cells on inducing ischemia [29] and into neural stem cells on inducing stroke [30]. In the same manner, the BM stem cells have also been shown to trans-differentiate into germ cells when gonadal function is compromised e.g. by treating with busulphan in female [31] and male [32] mice. Freshly prepared BM may also exhibit early tissue-specific markers but are up-regulated several folds when the function of organ is compromised [33].

Pluripotent stem cells are expected to be more primitive to TCSCs based on their developmental hierarchy (totipotent - pluripotent - multipotent- unipotent stem cells). This is also supported by various observations shown below. 
- $\quad$ Freshly isolated TCSC from the BM express tissue committed markers

- $\quad$ PSCs in BM acquire these markers after many days in culture

- $\quad$ TCSCs express c-Kit which is a more differentiated marker not expressed by PSCs.

Thus we propose following developmental hierarchy of stem cells in bone marrow (Figure:2) as opposed to the existing notion that HSC sit at the apex of hematopoietic system [1].

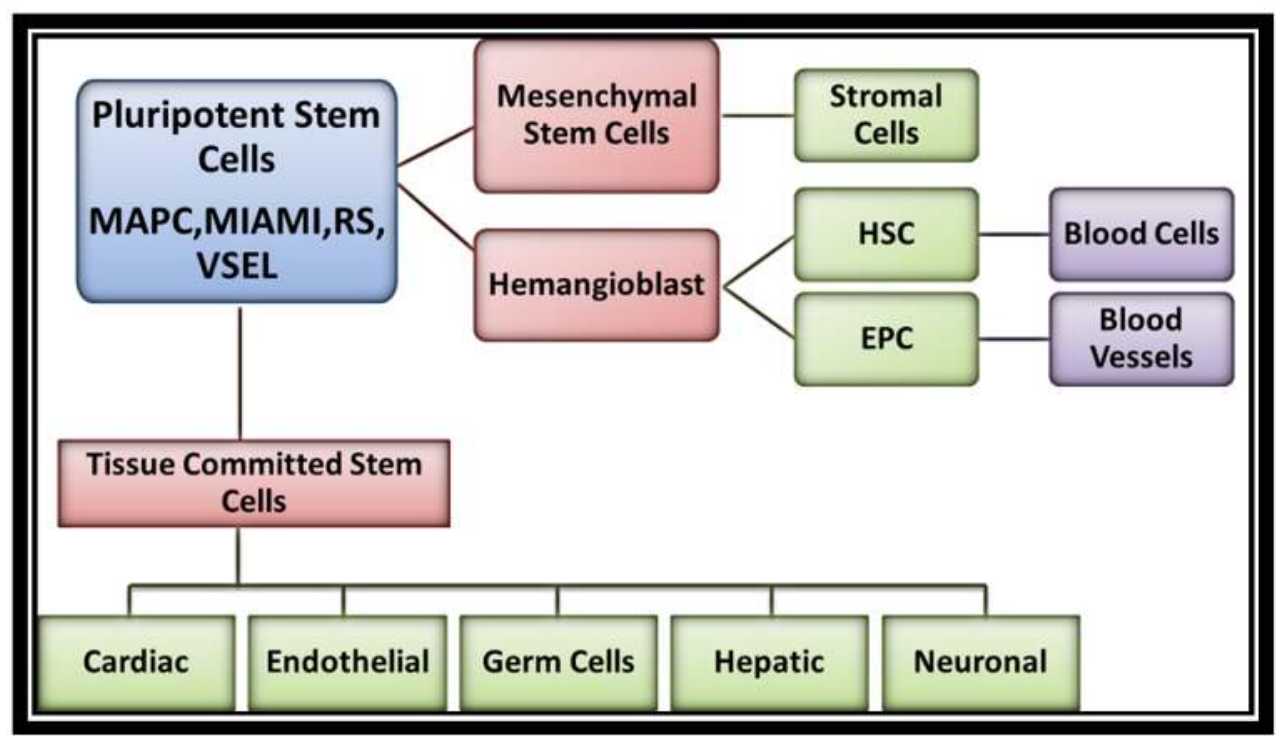

Figure 2. Developmental hierarchy of stem cells in bone marrow

The existing controversial literature that HSCs and MSCs can trans-differentiate into various lineages can be alternatively explained by the presence of these pluripotent stem cells. These PSCs interact closely with the MSCs by a process defined as emperipolesis [34]. The MSCs secrete SDF-1(Stromal Derived Factor-1) and other chemo-attractants thereby creating a homing environment for these pluripotent stem cells (express CXCR4). Thus isolated BM stem cells have always been contaminated with these PSCs which may have resulted in trans-differentiation and that HSCs/MSCs (being lineage restricted themselves) possibly do not account for the observed plasticity.

\section{Origin \& deposition of hematopoietic and non-hematopoietic stem cells in bone marrow}

Early embryogenesis is the most active period for the developmental migration/trafficking of stem cells. With the beginning of gastrulation and organogenesis, stem cells migrate to places where they establish rudiments for new tissues and organs. At certain points, of development stem cells colonize tissue specific niches, where they reside as a population of self renewing cells supplying new cells that effectively replace senescent ones or those undergoing apoptosis. 
In mammals the first primitive HSC are found in the yolk sac and first definitive HSC a few days later in the aorta-gonadmesonephros (AGM) region [35]. From the yolk sac and/or AGM region HSC migrate to the fetal liver (FL), which during the second trimester of gestation becomes the major mammalian hematopoietic organ. By the end of the second trimester of gestation, HSC leave the fetal liver and colonize BM tissue. Signals for the translocation of HSC from the fetal liver to BM are provided by the alpha chemokine - SDF1 that is secreted by osteoblasts lining the developing marrow cavities, marrow fibroblasts and endothelial cells. In response to SDF-1, HSC that expresses, SDF-1 receptor-a seven transmembrane-spanning $\mathrm{G}$ protein coupled CXCR4 receptor, leave the fetal liver and begin to home into BM where they finally establish adult haematopoiesis.

It is very likely that at this point BM is also colonized by several other nonhematopoietic stem cells that may circulate during organogenesis and rapid foetal growth/expansion. In support of this stem cells for different tissues express CXCR4 on their surface and follow an SDF-1 gradient. Thus the SDF-1-CXCR4 axis alone or in combination with other chemoattractants plays a crucial role in the accumulation of non-hematopoietic stem cells in developing BM $[36,37]$. These cells find a permissive environment to survive in BM, and may play an underappreciated role as a reserve pool of stem cells for organ/tissue regeneration during postnatal life.

The presence of these various populations of stem cells in the BM (Table 1) is a result of the 'developmental migration' of stem cells during ontogenesis and the presence of the permissive environment that attracts them to the BM tissue. HSC and other nonhematopoietic stem cells are actively chemoattracted by factors secreted by BM stromal cells and osteoblasts (e.g. SDF-1), hepatocyte growth factor (HGF)) and colonize marrow by the end of the second and the beginning of the third trimester of gestation [24].

It is assumed that these non-hematopoietic pluripotent stem cells are deposited in the BM during early embryogenesis and subsequently may be mobilized in stressed situations and circulate in the peripheral blood. Similarly due to the stress of delivery these cells may also be present in cord blood [18].

Interestingly various terminologies like MAPCs, MIAMI, RS cells etc. (Table 1) disappeared from the literature after initial publications and excitement except VSELs. Ratajczak and group have made tremendous contribution to the field of VSELs biology. At present various laboratories across the world are providing evidence to support the pluripotent property and potential of VSELs isolated from cord blood and bone marrow [38]. Possible reason being the method to isolate VSELs by flow cytometry described by Ratajczak and group could easily be replicated in various labs across the world.

\section{Very small embryonic like stem cells (VSELs)}

VSELs were identified by Ratajczak and group in 2006 by multi parameter sorting in adult murine BM. They express several morphological (e.g., relatively large nuclei containing euchromatin) and molecular (e.g. expression of SSEA-1, Oct4, Nanog, Rex1) markers 
characteristic for embryonic stem cells (ESCs) [33]. The morphology of the cells was investigated using transmission electron microscopy which showed their distinctive morphology and size differentiating VSELs from HSC in particular in terms of size (3-6 $\mu \mathrm{m}$ vs. 6-8 $\mu \mathrm{m}$ for HSC), chromatin structure and nucleus/cytoplasm ratio. Based on their small size, presence of PSC markers, distinct morphology (open-type chromatin, large nucleus, narrow rim of cytoplasm with multiple mitochondria) and ability to differentiate into all three germ layers, including mesoderm-derived cardiomyocytes, these cells were named very small embryoniclike stem cells. The true expression of Oct-4 and Nanog in BM-derived VSELs (BM-VSELs) was recently confirmed by demonstrating transcriptionally active chromatin structures of Oct 4 and Nanog promoters. A mechanism based on parent-of-origin-specific reprogramming of genomic imprinting that keeps VSELs quiescent in a dormant state in tissues has been described. VSELs highly express Gbx2, Fgf5, and Nodal, but express less Rex1/Zfp42 transcript as compared to ESC-D3s what suggests that VSELs are more differentiated than ICM-derived ESCs and share several markers with more differentiated EpiSCs. VSELs also highly express Dppa2, Dppa4, and Mvh, which characterize late migratory PGCs. The expression of germ line markers (Oct4 and SSEA-1) and modulation of somatic imprints suggest a potential developmental similarity between VSELs and germ line-derived primordial germ cells (PGCs) [39, 40].

Developmental Origin of VSELs: VSELs are epiblast-derived PSCs deposited early during embryonic development in developing organs as a potential reserve pool of precursors for TCSCs and thus this population has an important role in tissue rejuvenation and regeneration. VSELs originate from or are closely related to a population of proximal epiblast migratory Stem Cells (EpiSCs) that approximately at embryonic day (E)7.25 in mice, become specified to PGCs, and egress from the epiblast into extra-embryonic tissues (extraembryonic mesoderm) [41]. VSELs follow developmental route of HSCs colonizing together with HSCs first fetal liver and subsequently BM [37].

Thus PGCs, HSCs, and VSELs form all together a unique highly migratory population of interrelated Stem Cells (SCs) that could be envisioned to be a kind of "fourth highly migratory germ layer." [37]

Self-renewal and in vitro differentiation of VSELs: VSELs exist in various mouse organs [42], have been well-characterized and are capable of differentiating into all three lineages, supporting their true pluripotent character. Murine VSELs form embryoid body-like structures in co-cultures over C2C12 supportive cell line [24] and could become specified into HSCs after co-culture over OP-9 stroma cells. VSELs-derived HSCs harvested from these co-cultures reconstitute murine bone marrow after total body irradiation [43]. The Umbilical Cord Blood (UCB)-purified VSELs have also been reported to differentiate into neural cells [44] and after co-culture over OP-9 stroma cells were specified into HSCs similar to murine BM-derived VSELs [45]. Apart from umbilical cord blood and bone marrow, VSELs have also been reported in Wharton's jelly and gonadal tissue [46- 51]. Their presence amongst the MSCs in the Wharton's jelly is in agreement with observations made by other groups that MSCs contain a sub-population of more primitive stem cells [52] or even as postulated by Taichman and group [53] that VSELs are precursors of MSCs. Various studies 
have also reported that VSELs are mobilized into peripheral blood in response to injury/ stress in animal models [27,54-56] as well as in humans [28-30,57] - thus suggesting a role in regeneration and homeostasis.

\section{Our studies on VSELs in cord blood and bone marrow}

We studied the VSELs in UCB and discarded fraction of BM [46]. Usually the 'buffy coat' obtained after Ficoll-Hypaque centrifugation is considered to be rich in stem cells and used for various studies over several decades. However, we reported that VSELs settle along with the RBCs rather than getting enriched in the 'buffy coat (Figure:3). Similarly we found that the 'discarded' RBC pellet obtained during initial processing of bone marrow was also rich in VSELs. These results were explained on the basis of buoyancy. The adult stem cells have abundant cytoplasm, are relatively larger and thus observed in the buffy layer whereas the VSELs are the pluripotent stem cells, with high nucleo-cytoplasmic ratio, minimal cytoplasm and thus sink to the bottom of the tube along with the RBCs. These VSELs exhibited various pluripotent markers, like CD45-, CD133+ SSEA-4+. They also exhibit other primordial germ cell markers like Stella and Fragillis, thus supporting their origin from the epiblast stage embryo at the same time when PGCs migrate via the dorsal mesentry to the gonadal ridges to become a source of germ cells.

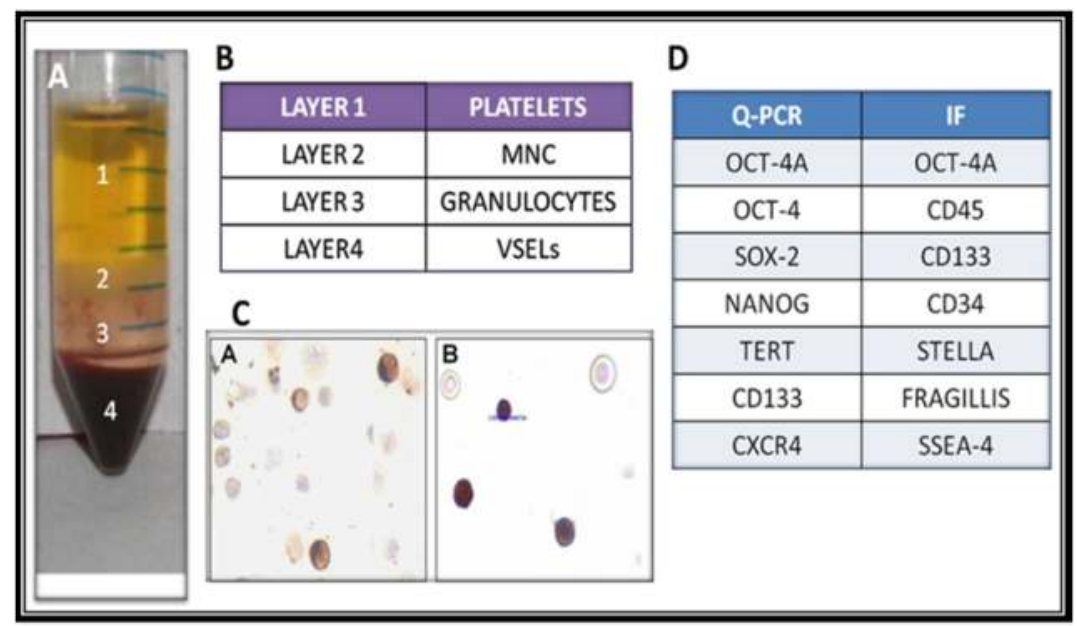

Figure 3. Isolation and characterization of VSELs from Cord Blood: A-Separation of cord blood into four layers on Ficoll-Hypaque; B-Description of cells observed in each layer separated; CImmunolocalization studies on MNC (A) and VSEL (B) using polyclonal Oct-4 (40X); D-Markers characterized on VSELs using Quantitative PCR and immunofluorescence

These studies have several implications e.g. the stem cell biologists should ask themselves what is getting banked in the cord blood banks. VSELs unknowingly get discarded and only adult stem cells (and progenitors) including HSCs and MSCs get banked. Similarly autologus stem cell therapy for various indications other than blood related diseases have resulted in 
minimal improvement. This may be explained since fate restricted progenitors HSC and MSC may have limited trans-differentiation ability. The pluripotent VSELs have maximum 'plasticity' and regenerative potential but are getting discarded unknowingly. This raises a valid question on the success of BM transplantation to treat blood related diseases. This success could be accounted for by the differentiation ability of progenitor cells into blood cells.

While doing immunolocalization studies to detect OCT-4 positive cells, we found the VSELs express nuclear OCT-4 whereas a slightly bigger cell in the 'buffy coat' collected from both the cord blood and bone marrow exhibited cytoplasmic OCT-4 (Figure:4). These are possibly the most immediate progenitors 'descendants' from VSELs. We also conducted immunolocalization studies on umbilical cord tissue in the region of Wharton's jelly which is rich in MSCs. Results show that the MSCs had cytoplasmic OCT-4 like HSCs and that there was a distinct subpopulation of small cells with nuclear OCT-4 and were the VSELs, based on their size (Figure:4). On a similar note, when we did immunolocalization of mouse bone marrow stem cells, we observed that the MSCs with typical fibroblast like morphology have cytoplasmic OCT-4 along with VSELs with nuclear OCT-4. The MSCs showed a very heterogeneous staining pattern. Only a sub population of MSCs were positive whereas other MSCs totally lacked cytoplasmic OCT-4. This possibly shows different differentiation state since as the cell gets more committed, cytoplasmic OCT-4 is no longer required.

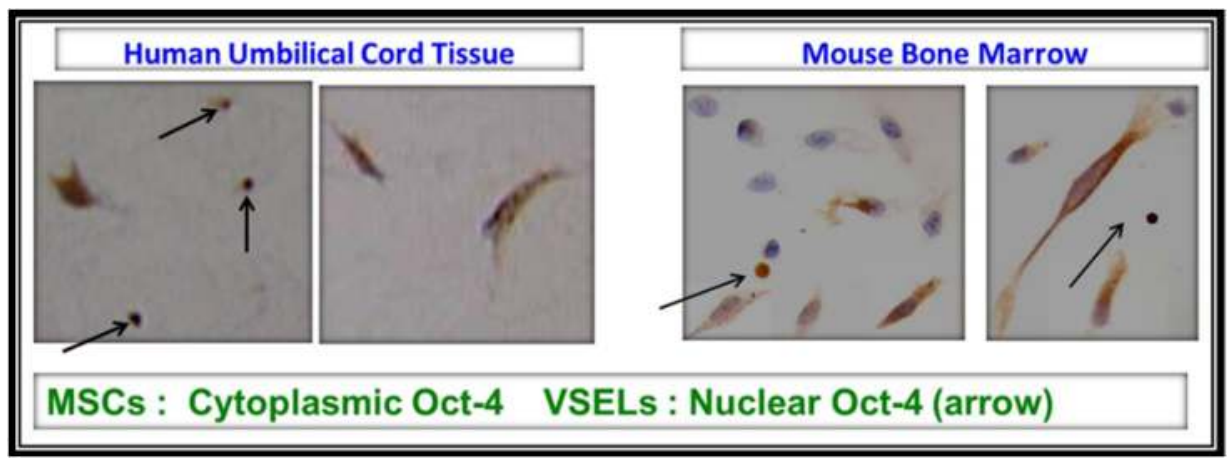

Figure 4. Immunolocalization of Oct-4 in umbillical cord tissue

Thus we concluded that the bone marrow compartment comprises of pluripotent VSELs and their immediate descendants like HSCs and MSCs. Also that the most primitive stem cell in the bone marrow is a pluripotent VSEL as shown in Figure 2. Being the most primitive stem cell in the BM, we hypothesize that VSEL will show best engraftment post transplantation and also will be best vehicle for gene therapy.

VSELs possibly undergo asymmetric cell division to self- renew and give rise to progenitors which further expand and differentiate to committed cell types. VSELs remain relatively quiescent throughout life, maintain long telomeres and are possibly the normal body stem cells which give rise to cancer stem cells (CSC) under certain unfavourable conditions. We propose that this transformation of a VSEL into CSC occurs due unidentified changes in the 
microenvironment. Recently it has also been reported that VSELs resist radiotherapy (because of their quiescent nature) that destroys all actively dividing stem cell population in the bone marrow [43]. The somatic microenvironment is also compromised by the radiotherapy. Thus although the VSELs persist, they are unable to reconstitute the bone marrow.

Existence of two stem cell populations in various adult body tissues is an interesting concept put forth by Li and Clevers [58]. They proposed that both quiescent (out of cell cycle and in a lower metabolic state) and active (in cell cycle and not able to retain DNA labels) stem cell subpopulations may coexist in several tissues like gut epithelium, hair follicle, bone marrow etc. We have generated data to show that similar two distinct populations of stem cells exist in mammalian gonads also. Interestingly similar stem cell biology persists in the mammalian gonads irrespective of sex and is possibly an evolutionarily conserved phenomenon as we have reported the same in mice, rabbits, sheep, monkey and humans $[48,50]$.

\section{VSELs in mammalian testis}

We have reported for the first time the presence of a distinct population of VSELs with nuclear OCT-4 in adult mouse [48] and human [47] testis, located towards the basement membrane of the seminiferous tubules. Besides, we also detected a progenitor stem cell population with cytoplasmic OCT-4, which was slightly bigger and had abundant cytoplasm. These cells showed extensive proliferation with cytoplasmic bridges as cords. As these cells differentiated further, the cytoplasmic OCT-4 was gradually lost. Interestingly the VSELs were found resistant to busulphan treatment which otherwise destroyed the dividing progenitors, haploid cells and damaged the somatic niche. Thus, it is evident that like the earlier report on bone marrow VSELs, gonadal VSELs are also resistant to oncotherapy. VSELs possibly undergo asymmetric cell division to give rise to progenitors, which undergo clonal expansion and may further differentiate into sperm (Figure:5)

\section{VSELs in mammalian ovary}

A gentle scraping of the adult ovary surface (mouse, rabbit, sheep, monkey and human) with a sterile blade releases stem cells in a Petri dish [50]. On H \& E staining, two distinct stem cell populations can be easily detected based on their size and differential OCT-4 staining pattern. The smaller stem cell population are smaller than the RBCs and exhibit nuclear OCT-4 whereas the slightly bigger population exhibits cytoplasmic OCT-4. Like cords in the testis, in the ovary we observed the presence of germ cell nests with cytoplasmic continuity representing extensive proliferation of progenitor stem cells. These stem cells were present in peri- menopausal human ovary and also persisted in mouse ovary after busulphan treatment. Like in the testis, the functionality of ovarian stem cells is also affected by a compromised niche.

Three weeks culture of peri-menopausal ovarian stem cells produces oocyte-like structures, embryo-like structures in vitro [50]. Thus the stem cells retain their functionality but are unable to differentiate because of a non-supportive niche. 


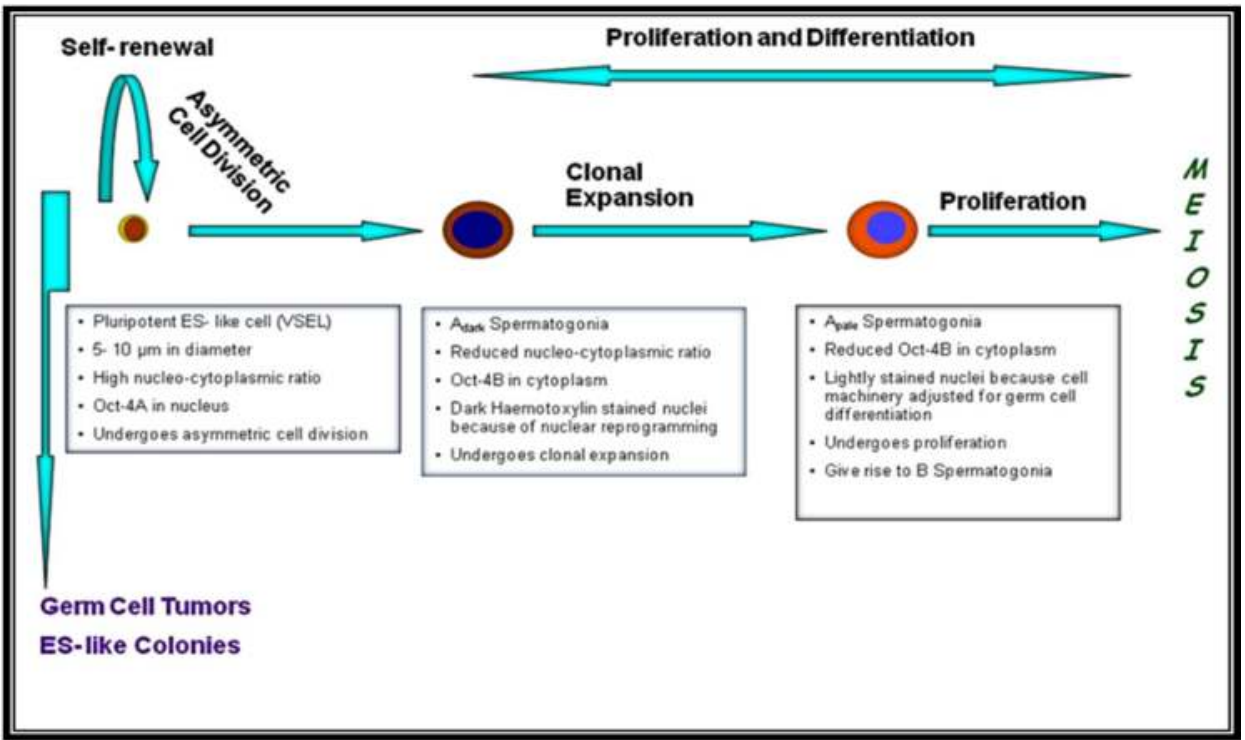

Figure 5. Revised scheme for premeiotic development of germ cells in adult human testis

\section{Significance of somatic microenvironment 'Niche' on VSELs functionality}

A relatively quiescent VSEL and actively dividing progenitor model that possibly exists in ovary, testis, bone marrow, cord blood and Wharton's jelly ensures that the 'master stem cell' undergoes very few rounds of DNA replication to prevent its genome from age-related changes and acquisition of errors during DNA replication.

Table 3 highlights the importance of the somatic niche in controlling the stem cell fate. It is the same VSEL that exists in different body organs but the niche dictates its fate [46].

\begin{tabular}{|l|l|l|l|}
\hline Sr.no & Tissue & $\begin{array}{l}\text { VSEL with } \\
\text { nuclear Oct-4 }\end{array}$ & $\begin{array}{l}\text { Progenitor stem cells with cytoplasmic Oct-4 } \\
\text { (tissue-specific progenitor stem cells) }\end{array}$ \\
\hline 1 & Testis & $\checkmark$ & Adark spermatogonia stem cells SSCs (Adark) \\
\hline 2 & Ovary & $\checkmark$ & Ovarian germ stem cells (OGSCs) \\
\hline 3 & $\begin{array}{l}\text { Bone marrow, } \\
\text { Umbilical cord } \\
\text { blood and tissue }\end{array}$ & $\checkmark$ & $\begin{array}{l}\text { Hematopoietic stem cells (HSC) } \\
\text { Mesenchymal stem cells (MSC) }\end{array}$ \\
\hline
\end{tabular}

Table 3. Details of Very Small Embryonic-Like Stem Cell-Derived Progenitors in Adult Human Tissues

The possible reason why extensive plasticity of VSELs is evident in bone marrow and cord blood (so many different kind of TCSCs have been described) in contrast to testis or ovary may be because the bone marrow niche is more permissive as compared to a 'gonadal' niche which is more specialized and thus restricted in nature. 


\section{VSELs and cancer}

Several years of cancer research suggests that cancers begin with genetic changes that occur over a period of 15 to 20 years and in few cases a link to chronic inflammation has been proposed e.g. in case of ovarian cancers, Barrett's esophagus etc. However, emerging literature suggests that quiescent VSELs distributed in various organs may be a cellular origin of cancer development. In 1855 Virchow proposed the embryonal rest hypothesis of tumor formation, based on histological similarities between tumors and embryonic tissues. This theory was later expanded by other pathologist including Julius Conheim, who suggested that tumors develop from residual embryonic remnants lost during developmental organogenesis [59]

Recently identified VSELs in various adult body tissues display morphology and markers characteristics as the pluripotent embryonic stem cells. These cells could support Virchow's concept of an embryonic origin of cancer. Possibly the somatic niche, which keeps the VSELs in a quiescent stage under normal circumstances, undergoes some changes which push the quiescent VSELs to an actively dividing state i.e. the tumor.

Wang et al [60] recently reported that persisting embryonic cells in adult mice and humans at the squamo-columnar junction are possibly the source of Barrett's metaplasia and that it does not arise from mutant cells. They proposed that certain precancerous lesions, such as Barrett's, initiate not from genetic alterations but from competitive interactions between cell lineages driven by opportunity. Similarly, almost $90 \%$ of ovarian cancers arise from the ovary surface epithelium which is also the niche for ovarian stem cells. It is being proposed that ovarian niche gets compromised with age leading to menopause [61,62] and also to cancer. It is essential to dissect out age related changes which lead to menopause and how they differ from those which lead to cancer. OCT-4, characteristic marker of VSELs is also a very good marker with high sensitivity and specificity for testicular germ cell tumors as well [63].

Cancer stem cells and VSELs with embryonic characteristics have a lot of similarities in terms of markers, telomere length, and resistance to radiotherapy; thus it may be proposed that VSELs transform into CSCs when certain not so well understood changes occur in the microenvironment. It is possible that inflammation may alter the niche where the VSELs reside. It is highly unlikely that a somatic cell which is relatively senescent and has short telomeres will dedifferentiate and acquire long telomeres to transform into a cancer stem cell. Keeping this in mind, because of a defect in stem cell in the bone marrow due to an altered niche - defective stem cell divisions occur and differentiation of such altered cells results in appearance of chromosomal defects in mononuclear cells picked by standard cytogenetic studies.

Identification of VSELs in adult tissues also opens new areas of investigation to elucidate how these cells contribute to the development of poorly differentiated tumors. Studying the biology of normal stem cells may help us to better understand the biology of cancer, and explain its resistance to radio-chemotherapy, ability to an unlimited proliferation and establishment of distant metastases. 


\section{Conclusions}

The field of BMT also stands to greatly benefit once VSELs potential are realized. A review article by Takizawa et al [64] makes an interesting reading and that despite advances in the field, timely availability of HLA matched BM is still problematic for patients including those who require multiple transplantations. In this context, in vitro expansion of HSC is crucial but not yet achieved. It is still hoped that a single HSC may suffice to induce long-term multilineage engraftment. Notta et al [65] reported the possibility of CD49f as a specific marker to isolate HSC. In the chapter we are proposing that VSELs possibly give rise to HSC and may be better cell source to induce engraftment. Using cell surface markers to identify cell types always has associated issues since surface phenotype of a cell can change depending on the activation status of the precursor cells. Danova-Alt et al [66] recently concluded that UCB VSELs neither have embryonic nor adult stem cell-like phenotype, are not equivalent to mouse VSELs, have aneuploid karyotype and should not be regarded as a stem cell population. However, they have studied Lin-/CD45-/CD34+ cells and not Lin/CD45-/CD133+ cells, which are the VSELs as described by Ratacjzak and group [38]. Further it remains to be confirmed whether the aneuploidies they report are a technical artefact, since no cell lineage is expected to be aneuploid.

VSELs could potentially be a real therapeutic alternative to the use of human ES cells since they do not form teratomas, are relatively quiescent and can be isolated from an autologous source. The fact that VSELs may differentiate in vitro into cells from all three germ layers makes these cells potential candidates in regenerative medicine. Finally, the mechanism by which VSELs could contribute to development of some malignancies could shed more light on origin of tumours. In conclusion it is of vital importance to evaluate if VSELs could be efficiently employed in the clinic. The work on VSELs is on the verge of development and in coming years will bring more answers to the potential of these cells.

\section{Key points of the Chapter}

- The trans-differentiation potential of the HSC or MSC from bone marrow is controversial and can be alternatively explained by the presence of pluripotent stem cells in the bone marrow.

- $\quad$ MAPC, MIAMI, VSELs, RS are possibly the same pluripotent stem cells, described differently by various investigators. All of these terminologies have disappeared over time in published literature except VSELs that are being widely studied by various groups across the world.

- VSELs are epiblast derived stem cells expressing pluripotent markers with high nucleocytoplasmic ratio and transcriptionally active chromatin. They have been isolated from various murine organs as well as from human organs including gonadal tissues, cord blood, bone marrow and Wharton's jelly.

- VSELs (with nuclear OCT-4) possibly are the most primitive cell type in BM and umbilical cord and give rise to HSC and MSC (with cytoplasmic OCT-4). 
- $\quad$ The quiescent nature of VSEL prevent it from tumor formation in vivo but an altered somatic niche may lead to transformation of VSEL to cancer stem cell - resulting in cancer.

\section{Author details}

Ambreen Shaikh and Deepa Bhartiya*

Stem Cell Biology Department, National Institute for Research in Reproductive Health (ICMR), Mumbai, India

\section{References}

[1] Doulatov S, Notta F, Laurenti E, Dick J (2012) Haematopoiesis: A Human Perspective. Cell Stem Cell.10:120-136.

[2] Friedenstein AJ, Chailakhjan RK, Lalykina KS (1970) The Development of Fibroblast Colonies in Monolayer Cultures of Guinea-Pig Bone Marrow and Spleen Cells. Cell Tissue Kinet.3:393-403.

[3] Li T and Wu Y (2011) Paracrine Molecules of Mesenchymal Stem Cells for Hematopoietic Stem Cell Niche. Bone Marrow Research doi:10.1155/2011/353878.

[4] Karagianni M, Schulze T, Bieback K (2012) Towards Clinical Application of Mesenchymal Stromal Cells: Perspectives and Requirements for Orthopaedic Applications .In: Davies J, editor. Tissue Regeneration - From Basic Biology to Clinical Application. InTech. ISBN: 978-953-51-0387-5.

[5] Orlic D, Kajstura J, Chimenti S, Jakoniuk I, Anderson SM, Li B, Pickel J, McKay R, Nadal-Ginard B, Bodine DM, Leri A, Anversa P (2001) Bone Marrow Cells Regenerate Infarcted Myocardium. Nature.6829:701-5.

[6] Lagasse E, Connors H, Al-Dhalimy M, Reitsma M, Dohse M, Osborne L, Wang X, Finegold M, Weissman IL, Grompe M (2000) Purified Hematopoietic Stem Cells Can Differentiate into Hepatocytes In Vivo. Nature Medicine.11:1229-34.

[7] Anzalone R, Lo Iacono M, Loria T, Di Stefano A, Giannuzzi P, Farina F, La Rocca G (2011) Wharton's Jelly Mesenchymal Stem Cells As Candidates for Beta Cells Regeneration: Extending the Differentiative and Immunomodulatory Benefits of Adult Mesenchymal Stem Cells for the Treatment of Type 1 Diabetes. Stem Cell Rev.2:342-63.

[8] Mezey E, Chandross KJ, Harta G, Maki RA, McKercher SR (2000) Turning Blood into Brain: Cells Bearing Neuronal Antigens Generated In Vivo from Bone Marrow. Science.5497:1779-82.

[9] Hess DC, Abe T, Hill WD, Studdard AM, Carothers J, Masuya M, Fleming PA, Drake CJ, Ogawa M (2004) Hematopoietic Origin of Microglial and Perivascular Cells in Brain. Exp Neurol. 2:134-44.

[10] Corti S, Locatelli F, Donadoni C, Strazzer S, Salani S, Del Bo R, Caccialanza M, Bresolin N, Scarlato G, Comi GP (2002) Neuroectodermal and Microglial Differentiation of Bone

${ }^{*}$ Corresponding Author 
Marrow Cells in the Mouse Spinal Cord and Sensory Ganglia. J Neurosci Res. 70(6):72133.

[11] Petersen BE, Bowen WC, Patrene KD, Mars WM, Sullivan AK, Murase N, Boggs SS, Greenberger JS, Goff JP (1999) Bone Marrow as a Potential Source of Hepatic Oval Cells. Science.284(5417):1168-70.

[12] Xu Y, Malladi P, Wagner DR, Longaker MT (2005) Adipose-Derived Mesenchymal Cells as a Potential Cell Source for Skeletal Regeneration. Curr Opin Mol Ther.4:300-5.

[13] Minguell JJ, Erices A (2006) Mesenchymal Stem Cells and the Treatment of Cardiac Disease. Exp Biol Med (Maywood). 231(1):39-49.

[14] Lee RH, Seo MJ, Reger RL, Spees JL, Pulin AA, Olson SD, Prockop DJ (2006) Multipotent Stromal Cells from Human Marrow Home to and Promote Repair of Pancreatic Islets and Renal Glomeruli in Diabetic NOD/SCID Mice. Proc Natl Acad Sci U S A.103(46):17438-43.

[15] Horwitz EM, Gordon PL, Koo WK, Marx JC, Neel MD, McNall RY, Muul L, Hofmann T (2002) Isolated Allogeneic Bone Marrow-Derived Mesenchymal Cells Engraft and Stimulate Growth in Children with Osteogenesis Imperfecta: Implications for Cell Therapy of Bone. Proc Natl Acad Sci U S A.99(13):8932-7.

[16] Orkin SH, Zon LI (2002) Hematopoiesis and Stem Cells: Plasticity Versus Developmental Heterogeneity. Nat Immunol.3(4):323-8.

[17] Wagers AJ, Sherwood RI, Christensen JL, Weissman IL (2002) Little Evidence for Developmental Plasticity of Adult Hematopoietic Stem Cells. Science.297(5590):2256-9.

[18] Ratajczak MZ, Zuba-Surma EK, Wojakowski W, Ratajczak J, Kucia M (2008) Bone Marrow- Home of Versatile Stem Cells. Transfus Med Hemother. 35(3):248-259.

[19] Jiang Y, Vaessen B, Lenvik T, Blackstad M, Reyes M, Verfaillie CM (2002) Multipotent Progenitor Cells can be Isolated from Postnatal Murine Bone Marrow, Muscle, and Brain. Exp Hematol.30: 896-904.

[20] D’Ippolito G, Diabira S, Howard GA, Menei P, Roos BA, Schiller PC (2004) MarrowIsolated Adult Multilineage Inducible (MIAMI) Cells, a Unique Population of Postnatal Young and Old Human Cells with Extensive Expansion and Differentiation Potential. J Cell Sci. 117:2971-2981.

[21] Colter DC, Sekiya I, Prockop DJ (2001) Identification of a Subpopulation of Rapidly SelfRenewing and Multipotential Adult Stem Cells in Colonies of Human Marrow Stromal Cells. Proc Natl Acad Sci U S A. 98:7841-7845.

[22] Pacini S, Carnicelli V, Trombi L, Montali M, Fazzi R, Lazzarini E, Giannotti S, Petrini M (2010) Constitutive Expression of Pluripotency-Associated Genes in Mesodermal Progenitor Cells (MPCs). PLoS ONE 5(3): e9861. doi:10.1371/journal.pone.0009861.

[23] Beltrami AP, Cesselli D, Bergamin N, Marcon P, Rigo S, Puppato E, D'Aurizio F, Verardo R, Piazza S, Pignatelli A, Poz A, Baccarani U, Damiani D, Fanin R, Mariuzzi L, Finato N, Masolini P, Burelli S, Belluzzi O, Schneider C, Beltrami CA (2007) Multipotent Cells can be Generated In Vitro from Several Adult Human Organs (Heart, Liver And Bone Marrow). Blood.110:3438-3446. 
[24] Kucia M, Reca R, Campbell FR, Zuba-Surma E, Majka M, Ratajczak J, Ratajczak MZ (2006) A Population of Very Small Embryonic-Like (VSEL) CXCR4(+)SSEA-1(+)Oct-4+ Stem Cells Identified in Adult Bone Marrow. Leukemia 20:857-869.

[25] Ratajczak MZ, Kucia M, Reca R, Majka M, Janowska- Wieczorek A, Ratajczak J (2004) Stem Cell Plasticity Revisited: CXCR4-Positive Cells Expressing mRNA for Early Muscle, Liver and Neural Cells 'Hide Out' in the Bone Marrow. Leukemia. 18:29-40.

[26] Asahara $\mathrm{T}$ and Kawamoto A (2004) Endothelial progenitor cells for postnatal vasculogenesis. Am J Physiol Cell Physiol 287:C572-C579.

[27] Kucia MJ, Wysoczynski M, Wu W, Zuba-Surma EK, Ratajczak J, Ratajczak MZ (2008) Evidence that Very Small Embryonic-Like Stem Cells are Mobilized into Peripheral Blood. Stem Cells. 26(8):2083-2092.

[28] Wojakowski W, Tendera M, Kucia M, Zuba-Surma E, Paczkowska E, Ciosek J, Hałasa M, Król M, Kazmierski M, Buszman P, Ochała A, Ratajczak J, Machaliński B, Ratajczak MZ (2009) Mobilization of Bone Marrow-Derived Oct-4+ SSEA-4+ Very Small Embryonic-Like Stem Cells in Patients with Acute Myocardial Infarction. J Am Coll Cardiol. 53(1):1-9.

[29] Abdel-Latif A, Zuba-Surma EK, Ziada KM, Kucia M, Cohen DA, Kaplan AM, Van Zant G, Selim S, Smyth SS, Ratajczak MZ (2010) Evidence of Mobilization of Pluripotent Stem Cells into Peripheral Blood of Patients with Myocardial Ischemia. Exp Hematol.38(12):1131-1142.

[30] Paczkowska E, Kucia M, Koziarska D, Halasa M, Safranow K, Masiuk M, Karbicka A, Nowik M, Nowacki P, Ratajczak MZ, Machalinski B (2009) Clinical Evidence that Very Small Embryonic-Like Stem Cells are Mobilized into Peripheral Blood in Patients after Stroke. Stroke. 40(4):1237-1244.

[31] Johnson J, Bagley J, Skaznik-Wikiel M, Lee HJ, Adams GB, Niikura Y, Tschudy KS, Tilly JC, Cortes ML, Forkert R, Spitzer T, Iacomini J, Scadden DT, Tilly JL (2005) Oocyte Generation in Adult Mammalian Ovaries by Putative Germ Cells in Bone Marrow and Peripheral Blood. Cell.122(2):303-15.

[32] Nayernia K, Lee JH, Drusenheimer N, Nolte J, Wulf G, Dressel R, Gromoll J, Engel W (2006) Derivation of Male Germ Cells from Bone Marrow Stem Cells. Laboratory Investigation 86:654-663.

[33] Ratajczak MZ, Liu R, Marlicz W, Blogowski W, Starzynska T, Wojakowski W, ZubaSurma E (2011) Identification of Very Small Embryonic/Epiblast-Like Stem Cells (Vsels) Circulating in Peripheral Blood During Organ/Tissue Injuries. Methods Cell Biol.103:3154.

[34] Kucia M, Wysoczynski M, Ratajczak J, Ratajczak MZ (2008) Identification of Very Small Embryonic Like Stem Cells (VSEL) in Bone Marrow. Cell Tissue Res.331(1):125-34.

[35] Ivanovs A, Rybtsov S, Welch L, Anderson RA, Turner ML, Medvinsky A (2011) Highly Potent Human Hematopoietic Stem Cells First Emerge in the Intraembryonic AortaGonad-Mesonephros Region. J Exp Med. 208(12):2417-27.

[36] Kucia M, Zuba-Surma E,Wysoczynski ,Dobrowolska H, Reca R, Ratajczak J, Ratajczak MZ (2006) Physiological and Pathological Consequences of Identification of Very Small 
Embryonic Like (Vsel) Stem Cells in Adult Bone Marrow J Physiol Pharmacol.57 Suppl 5:5-18.

[37] Zuba-Surma EK, Kucia M, Rui L, Shin DM, Wojakowski W, Ratajczak J, Ratajczak MZ (2009) Fetal Liver Very Small Embryonic/Epiblast Like Stem Cells Follow Developmental Migratory Pathway of Hematopoietic Stem Cells. Ann N Y Acad Sci. 1176:205-18.

[38] Ratajczak MZ, Shin DM, Liu R, Mierzejewska K, Ratajczak J, Kucia M, Zuba-Surma EK (2012) Very Small Embryonic/Epiblast-Like Stem Cells (Vsels) and their Potential Role in Aging and Organ Rejuvenation - An Update and Comparison to Other Primitive Small Stem Cells Isolated from Adult Tissues. Aging (Albany NY). [Epub ahead of print].

[39] Shin DM, Zuba-Surma EK, Wu W, Ratajczak J, Wysoczynski M, Ratajczak MZ, Kucia M (2009) Novel Epigenetic Mechanisms that Control Pluripotency and Quiescence of Adult Bone Marrow Derived Oct4(+) Very Small Embryonic-Like Stem Cells. Leukemia. 23:2042-2051.

[40] Shin DM, Liu R, Klich I, Wu W, Ratajczak J, Kucia M, Ratajczak MZ (2010) Molecular Signature of Adult Bone Marrow-Purified Very Small Embryonic-Like Stem Cells Supports their Developmental Epiblast/Germ Line Origin. Leukemia. 24:1450-1461.

[41] Hayashi K, de Sousa Lopes SM, Surani MA (2007). Germ Cell Specification in Mice. Science 316:394-396.

[42] Zuba-Surma EK, Kucia M, Wu W, Klich I, Lillard JW Jr, Ratajczak J, Ratajczak MZ. (2008). Very Small Embryonic-Like Stem Cells Are Present in Adult Murine Organs: Imagestream-based Morphological Analysis and Distribution Studies. Cytometry A 73A(12):1116-1127.

[43] Ratajczak J, Wysoczynski M, Zuba-Surma E, Wan W, Kucia M, Yoder MC, Ratajczak MZ (2011). Adult Murine Bone Marrow-Derived Very Small Embryonic-Like Stem Cells Differentiate into the Hematopoietic Lineage after Coculture over OP9 Stromal Cells. Exp Hematol 39(2):225-237.

[44] McGuckin C, Forraz N, Baradez MO, Basford C, Dickinson AM, Navran S, Hartgerink JD (2006). Embryonic-Like Stem Cells from Umbilical Cord Blood and Potential for Neural Modeling. Acta Neurobiol Exp (Wars) 66(4):321-329.

[45] Ratajczak J, Zuba-Surma E, Klich I, Liu R, Wysoczynski M, Greco N, Kucia M, Laughlin MJ, Ratajczak MZ (2011) Hematopoietic Differentiation of Umbilical Cord BloodDerived Very Small Embryonic/Epiblast-Like Stem Cells Leukemia 25(8):1278-85.

[46] Bhartiya D, Shaikh A, Nagvenkar P, Kasiviswanathan S, Pethe P, Pawani H, Mohanty S, Rao SG, Zaveri K, Hinduja I (2012) Very Small Embryonic-Like Stem Cells with Maximum Regenerative Potential get Discarded during Cord Blood Banking and Bone Marrow Processing for Autologous Stem Cell Therapy. Stem Cells Dev 21(1):1-6.

[47] Bhartiya D, Kasiviswanathan S, Unni SK, Pethe P, Dhabalia JV, Patwardhan S, Tongaonkar HB (2010) Newer Insights into Premeiotic Development of Germ Cells in Adult Human Testis using Oct-4 as a Stem Cell Marker. J Histochem Cytochem 58(12):1093-1106. 
[48] Bhartiya D, Sriraman K, Parte S (2012) Stem Cell Interaction with Somatic Niche may hold the Key to Fertility Restoration in Cancer Patients. Obstet and Gynec Intl. doi:10.1155/2012/921082.

[49] Bhartiya D, Kasiviswanathan S, Shaikh A (2012) Cellular Origin of Testis derived Pluripotent Stem Cells: A Case for VSELs. Stem Cells Dev. 21(5):670-674.

[50] Parte S, Bhartiya D, Telang J, Daithankar V, Salvi V, Zaveri K, Hinduja I (2011) Detection, Characterization, and Spontaneous Differentiation In Vitro of Very Small Embryonic-Like Putative Stem Cells in Adult Mammalian Ovary. Stem Cells Dev 20(8):1451-64.

[51] Virant-Klun I, Zech N, Rozman P, Vogler A, Cvjeticanin B, Klemenc P, Malicev E, Meden-Vrtovec H (2008) Putative stem cells with an embryonic character isolated from the ovarian surface epithelium of women with no naturally present follicles and oocytes. Differentiation 76(8):843-856.

[52] Anjos-Afonso F, Bonnet D (2007) Nonhematopoietic/Endothelial SSEA-1+ Cells Define the most Primitive Progenitors in the Adult Murine Bone Marrow Mesenchymal Compartment. Blood 109(3):1298-1306.

[53] Taichman RS, Wang Z, Shiozawa Y, Jung Y, Song J, Balduino A, Wang J, Patel LR, Havens AM, Kucia M, Ratajczak MZ, Krebsbach PH (2010) Prospective Identification and Skeletal Localization of Cells Capable of Multilineage Differentiation In Vivo. Stem Cells Dev 19(10):1557-1570.

[54] Dawn B, Tiwari S, Kucia MJ, Zuba-Surma EK, Guo Y, Sanganalmath SK, Abdel-Latif A, Hunt G, Vincent RJ, Taher H, Reed NJ, Ratajczak MZ, Bolli R (2008) Transplantation of Bone Marrow-Derived Very Small Embryonic-Like Stem Cells Attenuates Left Ventricular Dysfunction and Remodeling after Myocardial Infarction.Stem Cells 26(6):1646-1655.

[55] Huang Y, Kucia M, Hussain LR, Wen Y, Xu H, Yan J, Ratajczak MZ, Ildstad ST (2010) Bone Marrow Transplantation Temporarily Improves Pancreatic Function in Streptozotocin-Induced Diabetes: Potential Involvement of Very Small Embryonic-Like Cells. Transplantation 89(6):677-685.

[56] Zuba-Surma EK, Kucia M, Dawn B, Guo Y, Ratajczak MZ, Bolli R (2008) Bone MarrowDerived Pluripotent Very Small Embryonic-Like Stem Cells (VSELs) are Mobilized after Acute Myocardial Infarction. J Mol Cell Cardiol 44(5):865-873.

[57] Sovalat H, Scrofani M, Eidenschenk A, Pasquet S, Rimelen V, Hénon P (2011) Identification and Isolation from either Adult Human Bone Marrow or G-CSFMobilized Peripheral Blood of CD34(+)/CD133(+)/CXCR4(+)/ Lin(-)CD45(-) Cells, featuring Morphological, Molecular, and Phenotypic Characteristics of Very Small Embryonic-Like (VSEL) Stem Cells. Exp Hematol 39(4):495-505.

[58] Li L, Clevers H (2010) Coexistence of Quiescent and Active Adult Stem Cells in Mammals. Science 327(5965):542-5.

[59] Kucia M, Ratajczak MZ (2006) Stem Cells as a Two Edged Sword-From Regeneration to Tumor Formation. J Physiol Pharmacol 57 Suppl 7:5-16. 
[60] Wang X, Ouyang H, Yamamoto Y, Kumar PA, Wei TS, Dagher R, Vincent M, Lu X, Bellizzi AM, Ho KY, Crum CP, Xian W, McKeon F (2011) Residual Embryonic Cells as Precursors of a Barrett's-Like Metaplasia. Cell 145:1023-1035.

[61] Massasa E, XS Costa and HS Taylor (2010) Failure of the Stem Cell Niche rather than Loss of Oocyte Stem Cells in the Aging Ovary. Aging 2:1-2.

[62] Niikura Y, T Niikura and JL Tilly (2009) Aged Mouse Ovaries Possess Rare Premeiotic Germ Cells that can Generate Oocytes Following Transplantation into a Young Host Environment. Aging 1:971-978.

[63] Gillis AJ, Stoop H, Biermann K, van Gurp RJ, Swartzman E, Cribbes S, Ferlinz A, Shannon M, Oosterhuis JW, Looijenga LH (2011) Expression and Interdependencies of Pluripotency Factors LIN28, OCT3/4, NANOG And SOX2 in Human Testicular Germ Cells and Tumours of the Testis. Int J Androl 34e160-74.

[64] Takizawa H, Schanz U, Manz MG (2011) Ex Vivo Expansion of Hematopoietic Stem Cells:Mission Accomplished? Swiss Med Wkly 141:w13316

[65] Notta F, Doulatov S, Laurenti E, Poeppl A, Jurisica I, Dick JE (2011) Isolation of Single Human Hematopoietic Stem Cells Capable of Long-term Multilineage Engraftment. Science 333(6039):218-21.

[66] Danova-Alt R, Heider A, Egger D, Cross M, Alt R (2012) Very Small Embryonic-Like Stem Cells Purified from Umbilical Cord Blood Lack Stem Cell Characteristics. PLoS ONE 7(4): e34899. doi:10.1371/journal.pone.

[67] Tao H, Ma DD (2003) Evidence for transdifferentiation of human bone marrow-derived stem cells: recent progress and controversies. Pathology 35(1):6-13. 